\title{
DEVELOPMENT OF PROVIDING PUBLIC SERVICES IN THE ECONOMY AS A GUARANTEE OF EFFICIENCY IN EUROPEAN INTEGRATION PROCESSES
}

\author{
Natalija Berlach ${ }^{1}$, Galina Striiashko²
}

\begin{abstract}
The transitional period, in which most of European and the world countries today are, is in need of renewal and continuity of integration processes in vital areas to which the economic sphere itself belongs. Ensuring the introduction of universally accepted standards for the provision of public services in the economy into the practice of public administration actors is today a priority task of absolutely all countries that have declared in their Basic Law the principles of the rule of law and the rule by law, the recognition of a person, its life and health as the highest value. Significant obstacles to the gradual and systematic nature of such activities, determined by the aggravation of social tension in society, external aggression, the peculiarities of domestic doctrine and legislation, which are formed using well-defined concepts, at the same time, today contain ambiguous provisions on content, in particular, the notion of public services, their varieties, procedures for their provision, performance indicators. The abovementioned causes the necessity to search for the best ways to eliminate the above inconsistencies, which lead to real inhibition of activities as to ensure the quality provision of public services in the economic sphere. Only the cautious implementation of the principles and criteria for evaluating the provision of public services, as implemented in foreign countries (Great Britain, Germany, the USA, France, Hungary, the Baltic States etc.), should take into account the peculiarities of social relations that have developed in a specific state, in particular, in Ukraine one should take into account the complications associated with the current crisis in the political and international situation and, first of all, the urgent need for service orientation of public administration bodies in the economy and the financial sphere. At the same time, the presence of such features should not negatively affect the principle of gradualness and the continuity of the implementation of international standards in this area. Methodology. The solution of the set purpose is realized using the cognitive potential of the system of philosophical, general scientific and special methods. The comparative legal method is dominant, which allowed determining the development directions of domestic statutory enactments in order to bring them in line with the generally accepted standards for the provision of public services, the experience of highly developed economies. Methods of grammatical review and interpretation of legal norms have contributed to identifying gaps and other shortcomings in legislation that regulates the provision of public services in the economy, developing proposals for its improvement. Practical implications. The introduction of effective, timely, and consecutive steps to ensure the provision of quality public services in the economy, based on the unification of the standards of developed countries in the world, which will mean the implementation of an important step towards the global economic crisis recovery. Moreover, an example of the development of public service functions in European countries will demonstrate real achievements of an important task of reformation in countries with less developed democracy and insufficiently high investment climate index.
\end{abstract}

Key words: public service, administrative service, efficiency of service provision in the economy, quality of service provision, guarantees of effectiveness of public administration of the economy.

JEL Classification: G18, 016

\footnotetext{
Corresponding author:

${ }^{1}$ State Research Institute of Ministry of Internal Affairs of Ukraine, Ukraine.

E-mail: 40natalija@gmail.com

${ }^{2}$ University of the State Fiscal Service of Ukraine, Ukraine.

E-mail: striashko@ukr.net
} 


\section{Introduction}

The key to the existence of a successful and socially oriented society is to direct the activities of executive authorities and local self-government bodies to ensure the maximum promotion of legal economic activity of subjects of various forms of ownership. The achievement of such a purpose is directly related today with the stability and quality of public services provided by the public administration in all countries of the world. National scientific doctrines contain provisions on the state and improvement of efficiency in this area. However, one cannot but recognize the significant differences in the indicators of the state and quality of public services provided, especially in the economic field, in European countries, which is associated with different historical conditions of their formation and development and the laws of development of their economic systems.

It is also worth agreeing with the observations of certain scholars that public services in the field of the economy are considered in the scientific sources of the post-Soviet camp (mostly legal) primarily as a process of servicing by individual actors, first of all by power entities (Tylchyk, 2011) while in the world such services are interpreted as a result of serving the society through both public services and other instruments of state regulation (monetary policy, taxation policy, etc.). The above provisions actualize the necessity for the scientific and practical search for ways to increase the efficiency of providing public and not just administrative services in the economy in the unity of the purpose of their development, taking into account national characteristics and integration aspirations, by unifying procedural aspects. Herewith, the study of the positive experience of individual countries in providing this direction of activities in relation to the prospects for its expansion becomes of special significance.

\section{Public service as a form of public administration activities to regulate economic relations}

In the USA, Canada, Singapore, Korea, Malaysia, Hungary, electronic governance is being implemented within the framework of the society's information development strategy, which is based on the coordination of priorities, circumstances, and resources available. Such e-government is primarily aimed at providing electronic access to the most commonly used public services, developed by the United Nations methodology, which involves four phases.

Thus, Singapore became the first country where in 1999 a large-scale government portal eCitizen Centre (www.ecitizen.gov.sg) was created. The portal supports several sections: business, defence, education, employment, healthcare, housing, law and order, and more. The Estonian government, in the framework of the implementation of the concept of "e-government", created and launched in June 2001 an Internet portal "Today I Decide" (Tana otsustan mina), through which any resident of the republic can take part in the governance - to express their opinion on what is happening in the country, to propose amendments to bills etc. In the USA, where ideas about the need to develop e-government were first announced at the state level in 1998, the launch of the firstgov.gov portal (now - usa.gov) was the result. Today, this system covers almost $80 \%$ of all institutions. Also in the USA, there is a nationwide program "First Priority - Customers", which involves monitoring the quality of services provided and studying consumer expectations. In Hungary, in 2001, an e-government program was introduced directed to integrate information technology development strategies and projects across sectors and government institutions to provide citizens with high-quality services. Today, the Office of the authorized minister coordinates 36 programs that are implemented in 17 state institutions, which ensures the transparency of governance and the quality of service provision. In Malaysia, reforms in implementing the system of electronic public services are being introduced by the Administrative Modernization \& Management Planning Unit under the Prime Minister Department (Tyshchenko, 2010). The objectives of these reforms are to ensure effective intra- and interdepartmental coordination and provide easier access to public services for economic entities and citizens. The process of improving the provision of public services is undoubtedly linked to adhering to the principle of customer feedback.

Regarding the current situation in Ukraine, scholars and government officials state that the main challenge for the development of e-government in the state is to ensure the electronic interaction of state information resources. Almost every state body faces the need for access to one or another state register or database. Moreover, as the researchers rightly point out, such access is an important means to ensure the quality of the tasks performed by authorized agents, including in the field of economic security (Pashko, Tylchyk, Kotuha, 2018).

E-procurement, an electronic declaration system, common customs territory etc., need integration with many state registries and databases for their full functioning. The lack of electronic interaction of state systems does not make it possible to simplify the procedure for providing services and to comply with the requirements of the Law of Ukraine "On Administrative Services" regarding the prohibition on requiring from the subjects information or data that are in other authorities, that is, have already been provided by citizens earlier (Resolution of the Cabinet of Ministers of Ukraine "On Approval of the Concept for the Development 
of the Digital Economy and Society of Ukraine for 2018-2020 and Approval of the Action Plan for its Implementation” as of January 17, 2018, № 67-p).

As Ya. Kail rightly points out, the analysis of foreign experience of countries such as Great Britain, the USA, Australia, Canada, Germany, Hungary, Poland, China, South Korea, the Netherlands, Brazil allowed identifying the main approaches and principles used in the world practice of the system of providing public services in the economy; these processes are carried out within the framework of administrative reforms, the main directions of which are: the provision of state and municipal services on the basis of public administration standards; implementation of reforms with widespread use of information and communication technologies, improvement of the provision of public services using the principle of consumer feedback over a long period of time. The ideology of this strategy is to ensure greater transparency of the public sector for consumers and improve the quality and availability of public services and information about them (Kail, 2010).

As an example of the development of the use of information technology for providing services in the economy that greatly simplify access to such services, it is appropriate to consider activities of separate units of the State Fiscal Service of Ukraine that presented an innovative project "Check and Drink". Within this project, software is proposed developed as a computer program, so all smartphone's owners can install this application. The Application enables checking the availability of enterprises' licenses for the production and sale of alcohol, as well as licenses for the sale of tobacco products in a particular region. Also, this Application simplifies access to information about the business entity and its production quality and is simultaneously aimed at preventing the sale of excisable products to minors. Each citizen can freely use the program and notify about violations, including on the part of representatives of fiscal bodies. Users of the application can make a complaint about a violation of legislation by company or enterprise, namely, inform about problems with a fiscal check, the sale of counterfeit products, the sale of products to minors, and other violations. The complaint is immediately mailed to the body of the State Fiscal Service of Ukraine and will be considered in the nearest future. It is envisaged that the program will enable creating equal business conditions, make the Odesa region more attractive for tourists, and increase state budget revenues from the sale of the excisable group of goods (Fighting the shadow turnover of the excisable group of goods can be using a smartphone).

It should be noted that the European Union in 1992 introduced the Anglo-Saxon concept "generic service" that means a minimal service of the established quality which is provided to any user by an affordable price. In addition to the concept "generic service" legislation of the European Union also includes a concept of "services provided under the authority of state bodies" enshrined in the General Agreement on Trade in Services. These services, according to the specified Agreement, are defined as "any services provided neither on a commercial basis nor on competition among these services' suppliers" (Simpson, 2004). Therefore, in the European Union, in addition to paid services, there are a number of services provided by the state free of charge and determined by the state in special orders.

\section{Criteria for distinguishing public services in order to satisfy public interest in the economy}

The concept "public services" has its characteristic features, which can be as common for several countries, so have some differences taking into account peculiarities of the interior of one or another country. In France, public services are characterised by the main four criteria: satisfaction of public interest, continuity, adaptability, equal access for everyone to services (Tykhomyrov, 2007), which can be used also in the process of analysing this category in other world countries, taking into consideration general trend of countries to satisfy human needs and direction to the improvement of quality of public services provided. We consider it appropriate to reveal the content of these criteria.

Continuity as the next criterion of public services is not less important. This criterion in France is represented in the following forms: liability in the event of a break in the provision of a public service; application of unpredictability theory; the right to strike of public service agents within the established limits, which should be preceded by corresponding notice in five days; forced engagement of personnel to perform work. Adaptability is manifested in the fact that public authority when taking the obligation of direct management of providing a public service, assigns it to those agents that are able to adapt services to generally recognized needs that exist within the country at the moment. Such a criterion is also quite important since the ability of the government to adequately react to urgent necessities of society is one of the preconditions for normal and economically and politically stable life of the country.

Equal access for all to public service should be understood as the impossibility to establish any discriminatory restrictions in relation to citizens consuming public services. Any restriction, if the need for its existence appears, should be general in nature and apply to all without exception. Equal access to public services is the reverse side of the rule of equality of all before public duties (Tykhomyrov, 2007).

The Basic Law of the Federal Republic of Germany as of 23 May 1949 provides for the possibility of transferring the function of public authorities to provide services to private organizations, keeping control over this 
activity and the possibility of its legislative regulation (Basic Law of the Federal Republic of Germany, 1949). The French Constitution also provides for the possibility of delegating the functions of providing services to private organizations through the issuance of relevant regulations (The Constitution of France, 1958). In the administrative system of France, there are administrative institutions that are more or less consistent with our idea of the department. One of the types of such institutions is the so-called services of national competence (services à compétence nationale-SCN).

The establishment of such services, in turn, was envisaged by Decree No. 97-463 as of May 9, 1997, and the services themselves were legally removed from the central administration. The difference between these services from the central administration lies in the fact that they do not participate in the formation of public policy, do not control its implementation, and act solely as its technical tool. In addition to the services of national competence in France, there are a number of independent administrative authorities (autorités administratives indépendentes - AAI), although they are government agencies, they have received full autonomy from the central administration in accordance with the law. As a rule, such independent administrative authorities may be called bureaus, commissions, councils, supreme councils, mediators, intermediaries (Kozyrin, 1996).

At the federation level in the USA, the system of executive authorities consists of the President, departments, government corporations, independent agencies, and other institutions. The legislation stipulates that among the abovementioned bodies, administrative bodies are only those that do not carry out military or foreign-policy functions and have the authority to make decisions on the legal status of individuals, that is, to decide on their rights and obligations. Administrative management implies "not just execution but management mainly through regulation, carried out with the help of the delegated to administration rulemaking and judicial powers" (Kozyrin, 1998). Article 82 of the Spanish Constitution regulates the procedure for the delegation of functions of the state through the adoption of a special law, indicating the terms of delegation, its boundaries and objectives, principles and criteria. For this purpose, the Constitution stipulates that "general Cortes may delegate powers to the government to issue statutory enactments that have the force of law on certain matters, except as provided for in this Constitution" (The Spanish Constitution, 1978).

Consideration of provisions of some statutory enactments of foreign countries can serve as an impetus for Ukraine to create a similar system of regulation of the sphere of providing public services, structure and organization of public administration bodies. Alongside with that, it should be noted that in the event of a decision on the feasibility of introducing such an experience in Ukraine, it is necessary to conduct a balanced analysis of the possibilities of implementing this experience, in whole or in part, as well as the usefulness of taking into account the provisions of the legislation of Spain regarding the timely delegation of functions (Manychil, 2012).

\section{Conclusions}

The analysis of scientific and normative sources for the provision of public services in the economy allows pointing out that the well-considered implementation of the principles and criteria for evaluating the provision of public services in foreign countries (Great Britain, Germany, the USA, France, Hungary etc.) should include consideration of the peculiarities of social relations developed in a particular state, in particular, as exemplified by Ukraine (one should take into account the complications associated with the current crisis in the political and international situation). At the same time, the presence of such features should not negatively affect the principle of gradualness and continuity of the implementation of international standards in this area.

The foreign experience of increasing the efficiency of providing public services in the economy indicates that these issues are most effectively solved within the framework of special programs for the development of public administration of the relevant area, in terms of the recognition and gradual implementation of one of the main tasks - raising the standards of public services, improving their organization and distribution, promoting entities with significant achievements in the provision of public services, in particular, in the economy. Investing in such projects may involve associations of business entities of individual regions, subject to the principles of transparency and voluntary.

The directions of improvement of the domestic legislation concerning the provision of public services taking into account foreign standards are singled out: a) the development of the theory of public services, that is, the consolidation of conceptual and categorical provisions, principles of public services, criteria for the quality of their provision etc. in the Concept of public services; b) unification of legal regulation of administrative procedures by adopting the relevant legal act; c) consolidation in legal acts of types of legal guarantees of ensuring the legality of the provision of public services: control over the activities of public administration entities in providing public services; the prosecution of public servants for refusing to provide a certain type of public service, etc.; d) bringing in line with European experience requirements for adoption, amendment, cancellation, and appeal of individual administrative acts that are the result of providing public services; e) further study of the role of discretion of public service providers and limitation of abuse of powers in the process of their implementation. 


\section{References:}

Tylchyk, V. (2011). Administrative and legal mechanism for the resolution of tax disputes: thesis for cand. sc. (Jurisprudence): 12.00.07. Tylchyk Viacheslav Viacheslavovych. Irpin.

Tyshchenko, O. (2010). International experience in implementing e-governance. Retrieved from: http://ena.lp.edu.ua/bitstream/ntb/14125/1/82_176-177_maket-ena-ntb\%28099\%29.pdf

Tylchyk, O., Pashko, P., Kotukha, O. (2018). Ontology of scientific cognition of shadow economy and economic shading. Baltic Journal of Economic Studies, 4(2), 151-158. doi: 10.30525/2256-0742/2018-4-2-151-158

On approval of the Concept for the development of the digital economy and society of Ukraine for 2018-2020 and approval of the action plan for its implementation: Order of the Cabinet of Ministers of Ukraine as of 17 January 2018 № 67-p. Retrieved from: https://www.kmu.gov.ua/ua/npas/pro-shvalennya-koncepciyi-rozvitku-cifrovoyiekonomiki-ta-suspilstva-ukrayini-na-20182020-roki-ta-zatverdzhennya-planu-zahodiv-shodo-yiyi-realizaciyi

Kail, Ya. Ya. (2010). Foreign experience of standardization of state and municipal services. National interests, priorities, and security, 21(78), 71-78.

Fighting the shadow turnover of the excisable group of goods can be using a smartphone. Press Service of the State Fiscal Service of Ukraine. Retrieved from: http://sfs.gov.ua/media-tsentr/novini/248812.html

Simpson R., Synkov O. M. (2004). Regulation of services of general interest in the EU. Study guide. K.: IIR KNU named after Taras Shevchenko.

Tikhomirov, Yu. A. (2007). Public services and law: scientific and practical guide. M.: Norma.

Basic Law of the Federal Republic of Germany as of 23 May 1949. Retrieved from: http://www.proektua.org/ uploads/zakon/Constitution_of_Germany.pdf

The constitution of France as of 3 June 1958. Retrieved from: http://www.megabook.ru/Article.asp?AID=641796 Kozyrin, A. N. (1996). Administrative law of foreign countries. Study guide. M.: Publishing House "SPARK".

Kozyrin, A. N. Public administration in foreign countries. Retrieved from: www.kozyrin.ru/userfiles/documents/ articleak.pdf

The Spanish Constitution as of 27 December 1978. Retrieved from: http://tehnorai.su/pr/konstituciya-ispaniiskachat-tekst.html

Manylich, L. I. (2012). Public services in the activity of the State Tax Service of Ukraine: organizational and legal principles [Text]: thesis for cand. sc. (Jurisprudence): 12.00.07. Manylich Liudmyla Ivanivna; National University of Life and Environmental Sciences of Ukraine. Kyiv. 